\title{
Depositional Environment Assessment of the Middle Miocene Sedimentary Rocks in Thien Ung - Mang Cau Structure, Block 04 - 3, Nam Con Son Basin
}

\author{
Ngoc Bao Pham ${ }^{1,}{ }^{*}$, Nghi Tran ${ }^{2}$, Dong Trung Tran ${ }^{3}$, Oanh Thi Tran ${ }^{1}$ \\ ${ }^{1}$ PetroVietnam University, Ba Ria - Vung Tau, Vietnam \\ ${ }^{2}$ Science Research \& Engineering Institute, Ba Ria - Vung Tau, Vietnam \\ ${ }^{3}$ Hanoi University of Science - VNU, Hanoi, Vietnam
}

ARTICLE INFO

Article history:

Received 15 $5^{\text {th }}$ Sept. 2021

Revised $09^{\text {th }}$ Jan. 2022

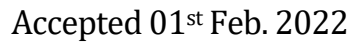

Keywords:

Depositional Environment,

Middle Miocene Sediment,

Nam Con Son Basin,

Seismic Attribute,

Thien Ung - Mang Cau

Structure.

\section{ABSTRACT}

Sediment depositional environments are one of the important scientific bases in evaluation the reservoir potential of sedimentary rocks. This article focuses on studying this issue for Middle Miocene sediments, Thien Ung Mang Cau structure, Block 04 - 3, Nam Con Son basin. The article has integrated the methods of well log interpretation, thin section analysis and seismic attribute analysis, combined with the results of paleontological analysis of VPI - Labs to identify depositional environments of Middle Miocene sediments in the case study area. The results of interpreting well log data show that the Middle Miocene sediments were deposited in the following environments: shallow marine, shoreline, mouth bars, delta front, prodelta and lower deltaic plain. These findings are also consistent with the results of petrographic and paleontological analysis. The results of petrographic analysis show that in the study area, there are 2 main groups of sedimentary rocks, which are clastic and carbonate rocks. In the thin sections, the following components were detected: glauconite clay is characterized of marine environment, carbonate fission and siderite ore which are characteristic of deltaic environments. While paleontological samples detected organic materials, such as algae, bitumen; and fossils such as Foraminifera, Da Gai and Oc Gai - typical for shallow marine environments. The results of the seismic attribute analysis for the Middle Miocene carbonate sediments of the structure have clarified that the carbonate is concentrated in the central and eastern uplift area. This distribution tends to fewer in the west. This finding is consistent when the authors compared to well correlation in the area (wells: $C-1 X, C-2 X, C-3 X$ and $C-4 X$ ) and also logically with the sedimentary principles.

${ }^{*}$ Corresponding author

E - mail: ngocpb@pvu.edu.vn

DOI: 10.46326/JMES.2022.63(1).03 


\title{
Tạp chí Khoa học Kỹ thuật Mỏ - Địa chất
}

Trang điện tử: http://tapchi.humg.edu.vn

\section{Nghiên cứu đặc điểm môi trường lắng đọng trầm tích Miocen giữa, cấu tạo Thiên Ưng - Mãng Cầu, lô 04 - 3, bể Nam Côn Sơn}

\author{
Phạm Bảo Ngọc ${ }^{1,}$, Trần Nghi ${ }^{2}$, Trần Trung Đồng ${ }^{3}$, Trần Thị Oanh ${ }^{1}$ \\ ${ }^{1}$ Trường Đại học Dầu khí Việt Nam, Bà Rịa - Vũng Tàu, Việt Nam \\ 2 Viện Nghiên cúu Khoa học và thiết kế Dầu khí biển, Bà Rịa - Vũng Tàu, Việt Nam \\ ${ }^{3}$ Trường Đại học Khoa học Tự nhiên Hà Nội - VNU, Hà Nội, Việt Nam
}

THÔNG TIN BÀI BÁO

Quá trình:

Nhận bài 15/09/2021

Sửa xong 09/01/2022

Chấp nhận đăng 01/02/2022

Tù̀ khóa:

Bể Nam Côn Sơn,

Cấu tạo Thiên Ưng - Mãng

Cầu,

Môi trường trầm tích,

Thuộc tính địa chấn,

Trầm tích Miocen giữa.
TÓM TẮT

Đặc điểm môi trường lắng đọng trầm tích là một yếu tố quan trọng trong việc đánh giá tiềm năng chứa của đá trầm tích. Bài báo tâp trung nghiên cứu vấn đề này cho trầm tích Miocen giữa, cấu tao Thiên Ưng - Mãng Cầu thuôc pham vi lô 04 - 3 của bể Nam Côn Sơn. Bài báo đã tích hơp phương pháp minh giải tài liệu địa vật lý giếng khoan, phương pháp phân tích lát mỏng thạch học và phương pháp phân tích thuộc tính địa chấn, kết hợp với kết quả phân tích cổ sinh của VPI - Labs để làm rổ một số bối cảnh lắng đong trầm tích Miocen giữa của khu vưc nghiên cúu. Kết quả minh giải tài liệu đia vất lý giếng khoan cho thấy, trầm tích Miocen giữa tại đây được lắng đọng trong các môi trường sau: môi trường biển nông (shallow marine), cứa sông (mouth bars), tiền châu thổ (delta front), sườn châuu thổ (prodelta) và phần thấp của đồng bằng châu thổ (lower deltaic plain). Điều này cũng khớp với kết quả phân tích thach hơc và cổ sinh. Kết quả phân tích thach hoc cho thấy khu vực nghiên cúu tồn tai 2 nhóm đá trầm tích chính, đó là nhóm đá trầm tích vụn co học và nhóm đá cacbonat. Trong mẫu thạch học trầm tích vụn cơ học phát hiện các thành phần: sét glauconit đặc trung cho môi trường biển, kết hach cacbonat và quặng siderit thường đặc trung cho môi trường sườn châu thổ. Trong khi các mấu phân tích cổ sinh phát hiên thành phần vât chất hũu cơ như rong tảo, bitum và các hóa thach tiêu biểu gồm Foraminifera, Da Gai và Ốc Gai - đây là các hóa thạch chỉ thị cho môi trường biển nông. Kết quả phân tích thuộc tính địa chấn cho đối tượng trầm tích cacbonat Miocen giữa của cấu tạo đã̃ làm rõ diẹn phân bố của trầm tích này tập trung tại khu vực khối nâng trung tâm và phía đông, càng ra xa đới nâng thì diên phân bố giảm dần. Kết quả này phù hợp khi các tác giả tiến hành liên kết các giếng khoan trong khu vực $(C-1 X, C-2 X, C-3 X$ và $C-4 X)$ và cũng logic với các quy luật trầm tích.

C 2022 Trường Đại học Mỏ - Địa chất. Tất cả các quyền được bảo đảm.
*Tác giả liên hệ

E - mail: ngocpb@pvu.edu.vn

DOI: 10.46326/JMES.2022.63(1).03

\section{Mở đầu}

Bể Nam Côn Sơn có diện tích gần 100.000 $\mathrm{km}^{2}$, nằm trong khoảng 6000' đến 9045' vĩ độ Bắc và $106^{\circ} 00^{\prime}$ đến $109^{\circ} 00^{\prime}$ kinh độ đông. Phía Đông 


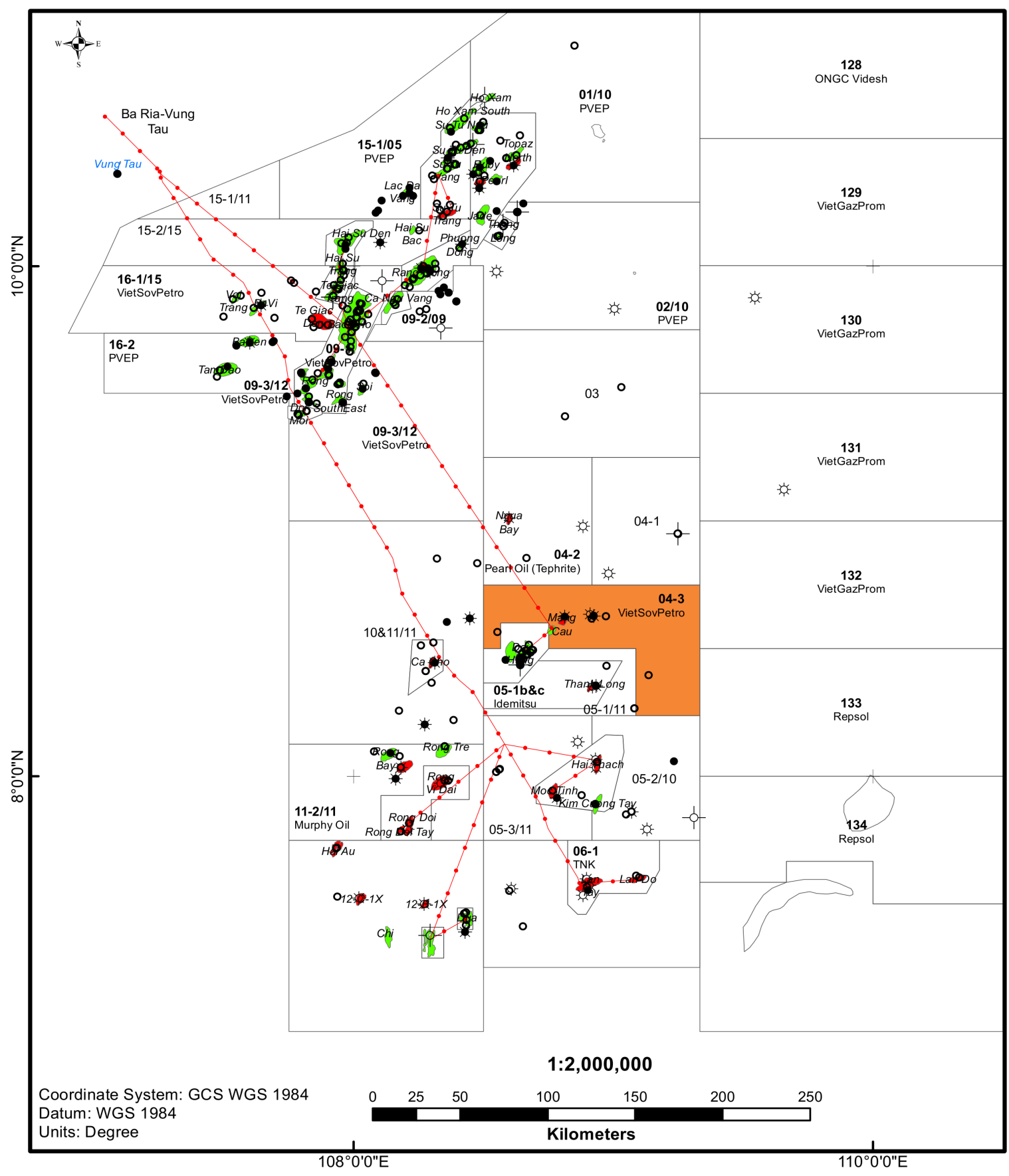

Hình 1. So đồ vị trí khu vực nghiên cứu bể nam Côn Sơn.

bắc của bể được giới hạn bởi đới trượt Tuy Hòa, phía tây bắc của bể là đới nâng Côn Sơn, phía tây nam là đới nâng Khorat - Natuna, còn phía đông là khu vực Tư Chính - Vũng Mây (Nguyễn, 2005). Độ sâu nước biển trong phạm vi bể thay đổi rất lớn, từ vài chục $\mathrm{m}$ ở phía Tây đến hơn $1.000 \mathrm{~m}$ ở phía đông. Cấu tạo Thiên Ưng - Mãng Cầu là một đới nâng dạng tuyến, hướng đông bắc - tây nam, thuộc lô 04 - 3, nằm trong phụ đới nâng Mãng Cầu của khu vực trung tâm bể nam Côn Sơn (Hình 1) (Mai, 2011; Vietsovpetro, 2011). Kích thước cấu tạo khoảng 20 x 15 km, nằm song song với đới nâng Côn Sơn. Trong khu vực nghiên cứu tồn tại chủ yếu các đứt gãy thuận, các đứt gãy này hoạt động khá phức tạp đóng vai trò chia cắt cấu trúc địa chất của khu vực. Cấu tạo này gồm 2 khối chính: khối Mãng Cầu có kích thước 5,0 x 2,5km và khối Thiên Ưng kích thước 9,0 x 2,0 km. 
Đây là một trong những cấu tạo có triển vọng dầu khí ở lô 04 - 3, đặc biệt là có tiềm năng chứa trong trầm tích Miocen giữa (Mai, 2011; Vietsovpetro, 2011). Hiểu được môi trường lắng đọng trầm tích của khu vực là một trong những nhiệm vụ quan trọng trong nghiên cứu, đánh giá chất lượng đá chứa. Chính vì vậy, bài báo đã kết hợp các tài liệu địa vật lý giếng khoan, tài liệu địa chấn và lát mỏng thạch học từ mẫu lõi để nghiên cứu đặc điểm môi trường lắng đọng trầm tích Miocen của khu vực nghiên cứu. Về đặc điểm địa tầng, khu vực nghiên cứu có các đơn vị địa tầng từ cổ đến trẻ như sau: móng trước Kainozoi, hệ tầng Dừa (tuổi Miocen sớm), hệ tầng Thông - Mãng Cầu (tuổi Miocen giữa), hệ tầng Nam Côn Sơn (Miocen muộn) và hệ tầng Biển Đông (Pliocen - Đệ Tứ). Như vậy, có thể thấy các trầm tích Oligocen vắng mặt trong khu vực cấu tạo Thiên Ưng - Mãng Cầu này.

\section{Cơ sở dữ liệu và phương pháp nghiên cứu}

Cơ sở dữ liệu: Bài báo sử dụng tài liệu địa vật lý giếng khoan của giếng khoan $\mathrm{C}-1 \mathrm{X}, \mathrm{C}-2 \mathrm{X}, \mathrm{C}$ $3 X$ và $C-4 X$ cùng với 30 lát mỏng thạch học trong phạm vi các giếng khoan đó. Bên cạnh đó, nhóm tác giả cũng sử dụng cube địa chấn $3 \mathrm{D}$ đã dịch chuyển chiều sâu trước cộng (PreStack Depth Migration - PSDM) bao phủ lô 04 - 3 (Hình 2). Đây là tài liệu địa chấn theo miền chiều sâu, được thu nổ năm 2007, tái xử lý năm 2019 cho chất lượng xử lý dịch chuyển các phản xạ địa chấn tốt hơn. Tài liệu địa chấn này là dữ liệu đầu vào quan trọng nhất nhằm minh giải các mặt phản xạ chính (Hình 3) và phân tích thuộc tính địa chấn đối tượng trầm tích của khu vực nghiên cứu

Để phân tích và minh giải được các dữ liệu nói trên phục vụ mục đích nghiên cứu, tập thể tác giả đã sử dụng các phương pháp sau đây:

\subsection{Phưong pháp minh giải tài liệu địa vật lý giếng khoan}

Dựa vào xu thế biến đổi hay hình dạng của đường cong gamma ray có thể xác định được môi trường thành tạo trầm tích. Thông qua sự biến đổi của đường cong gamma ray có thể cho biết sự thay đổi độ hạt của trầm tích (từ thô đến mịn hoặc từ mịn đến thô) cũng như sự thay đổi của năng lượng dòng chảy (như tốc độ năng lượng dòng chảy thấp hay cao, tần suất thay đổi liên tục hay không liên tục); từ đó luận giải được những môi trường lắng đọng trầm tích liên quan (Hình 4). Phương pháp này đã được các nhà khoa học trên thế giới áp dụng khá phổ biến trong các nghiên cứu về trầm tích từ những thập niên cuối của thế kỉ XX (Cant, 1992; Chow, 1995; Selley, 1978; Serra, 1989).

\subsection{Phưong pháp phân tích lát mỏng thạch học}

Mục đích của phương pháp phân tích lát mỏng thạch học dưới kính hiển vi phân cực nhằm xác định được thành phần và hàm lượng các

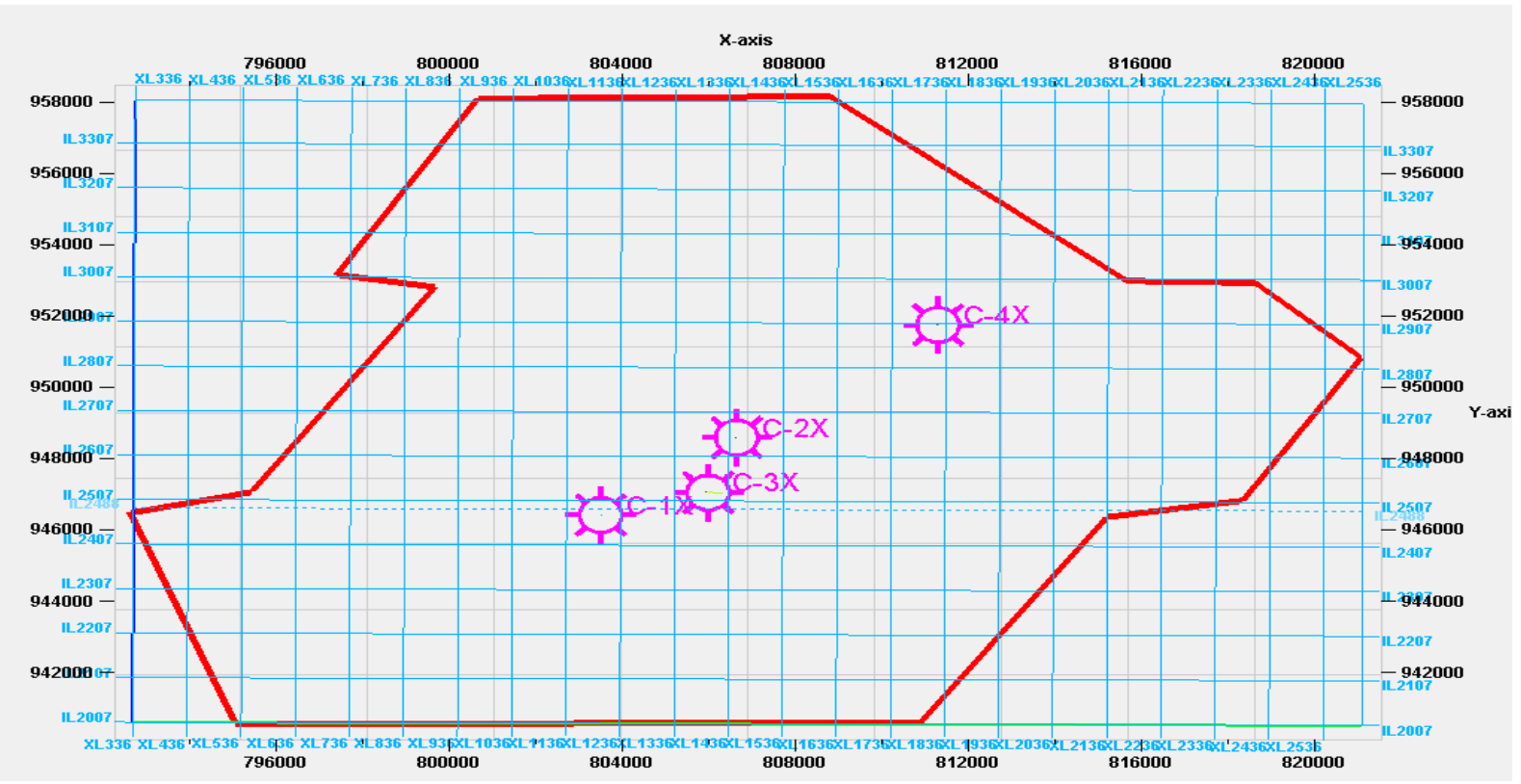

Hình 2. Cơ sở tài liệu địa chấn $3 D$ khu vực nghiên cúu. 


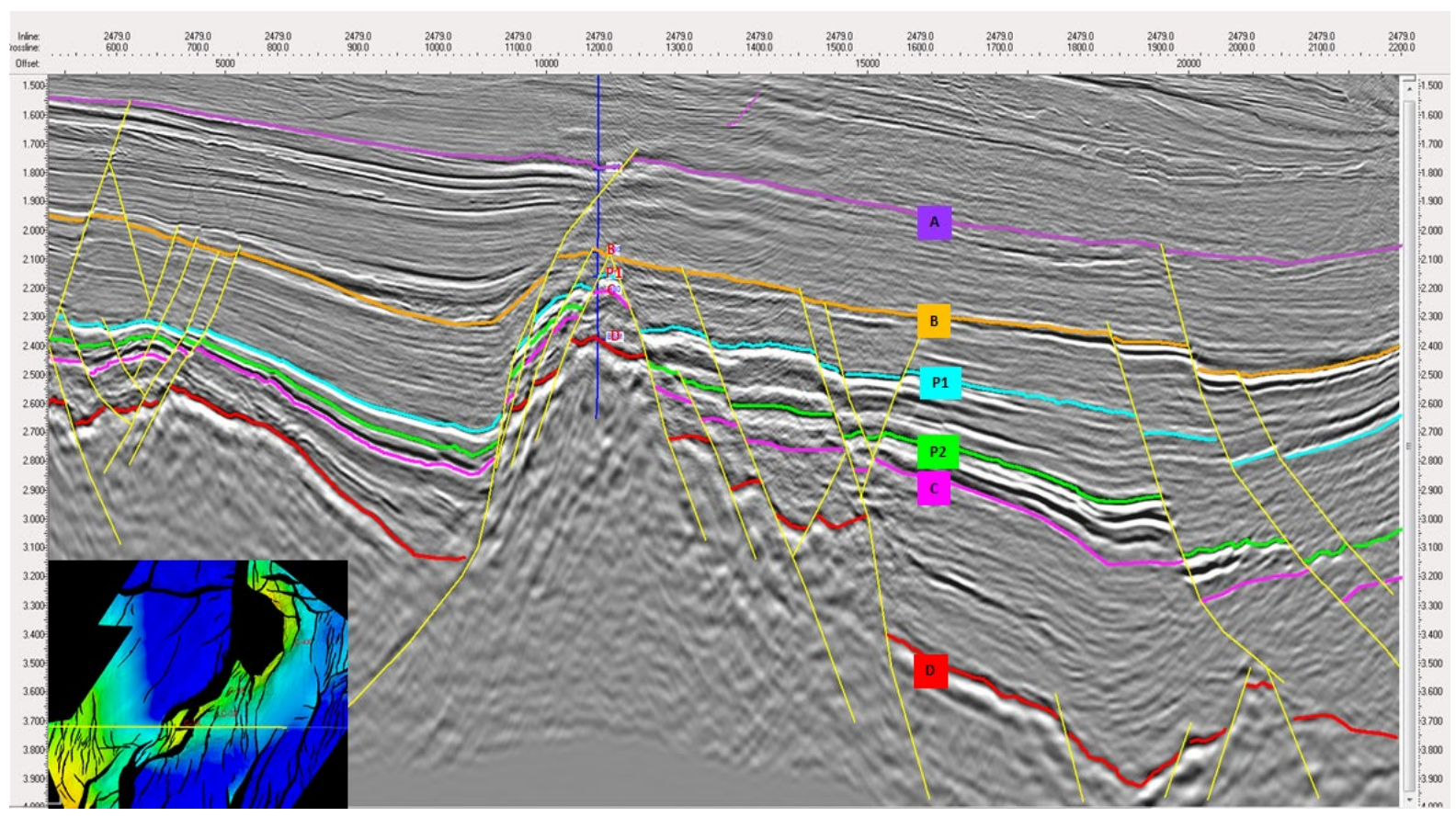

Hình 3. Mặt cắt địa chấn thể hiện các mặt phản xạ qua khu vực nghiên cúu.

\begin{tabular}{|c|c|c|c|c|c|}
\hline GR Log Pattern & Hình trụ & Hình phễu & Hình chuông & Hình quả trám & Hình răng cưa \\
\hline $\begin{array}{l}\text { Xu hướng } \\
\text { thay đổi } \\
\text { hình dạng } \\
\text { đường cong } \\
\text { gamma ray }\end{array}$ & Low GR High GR & $\begin{array}{l}\text { Coarse } \\
\text { Up \& } \\
\text { Sharp top }\end{array}$ & & s & 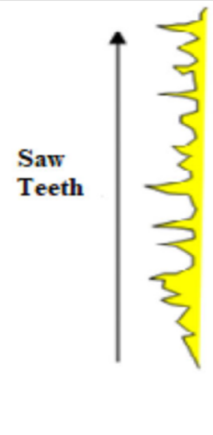 \\
\hline $\begin{array}{l}\text { Môi trường lắng } \\
\text { đọng trầm tích (phổ } \\
\text { biến) }\end{array}$ & $\begin{array}{l}\text { Môi trường lòng sông } \\
\text { (Fluvial channels, } \\
\text { thềm cacbonat } \\
\text { (carbonate shelf), phụ } \\
\text { lưu của châu thố } \\
\text { (prograding delta } \\
\text { distributaries), dụn cát } \\
\text { (Aeolian dunes) }\end{array}$ & $\begin{array}{l}\text { Môi trường sông } \\
\text { (river), cửa sông } \\
\text { (mouth bar), tiền châu } \\
\text { thổ (delta front) }\end{array}$ & $\begin{array}{l}\text { Bar cát (fluvial point } \\
\text { bar, tidal point bar), } \\
\text { kênh rạch ngập triểu } \\
\text { (deep tidal channel } \\
\text { fill), dồng bằng ngập } \\
\text { triểu (tidal flats), } \\
\text { deltaic channels }\end{array}$ & $\begin{array}{l}\text { Phần châu thổ ngập } \\
\text { triều chịu ảnh hưởng } \\
\text { của quá trình thay dổi } \\
\text { từ biển thoái sang biển } \\
\text { tiến (regressive to } \\
\text { transgressive shore } \\
\text { face delta) }\end{array}$ & $\begin{array}{l}\text { Đồng bằng ngập lũ } \\
\text { (fluvial flood plain), } \\
\text { khu vực thềm biển bị } \\
\text { ảnh hướng mạnh của } \\
\text { bão (storm dominated } \\
\text { shelf), đồng bằng } \\
\text { ngập triều (tidal flat), } \\
\text { dòng chảy bùn đá } \\
\text { (deris flow), hẻm } \\
\text { canyon (canyon fill) }\end{array}$ \\
\hline
\end{tabular}

Hình 4. Các kiểu môi trường lắng đọng trầm tích tương úng với các hình dạng đường cong gammaray (Can, 1992; Radwan, 2021).

khoáng vật (gồm thạch anh, fenspat và các khoáng vật phụ), hàm lượng xi măng, các loại mảnh đá; xác định kiến trúc và vi cấu tạo; xác định các tham số thạch học trầm tích như độ hạt (Md), độ cầu (Sf), độ chọn lọc (So), độ mài tròn (Ro), hệ số biến đổi thứ sinh (I), hệ số nén ép (Co). Các thông số này là cơ sở quan trọng để luận giải môi trường lắng đọng của trầm tích.

\subsection{Phương pháp minh giải và phân tích thuộc tính địa chấn}

Dựa trên các băng địa chấn tổng hợp qua các giếng khoan, tập thể tác giả tiến hành minh giải các mặt phản xạ, các hệ thống đứt gãy và thành lập bản đồ cấu trúc thông qua phần mềm Petrel 2016. Tiếp đó, nghiên cứu áp dụng phương pháp phân 
tích thuộc tính địa chấn nhằm làm nổi bật lên diện phân bố của trầm tích cacbonat Miocen giữa của khu vực nghiên cứu. Thuộc tính địa chấn (seismic attributes) là tất cả các đặc điểm của trường sóng như hình dạng, biên độ, tần số, tốc độ truyền sóng phản xạ,... Đối với mỗi kiểu trầm tích khác nhau sẽ phản ánh những đặc trưng trường sóng địa chấn khác nhau do đặc điểm thành phần thạch học khác nhau.

Nghiên cứu tập trung vào thuộc tính biên độ để phân tích những điểm dị thường nhằm khoanh vùng phân bố đá cacbonat ám tiêu trong khu vực nghiên cứu.

Dựa vào đặc trưng động học của phản xạ địa chấn, bài báo sẽ phân tích các thuộc tính địa chấn nhằm dự báo sự phân bố cacbonat ám tiêu trong Miocen giữa. Thuộc tính địa chấn là một phép đo bất kỳ của tài liệu địa chấn để nâng cao khả năng hiển thị, định lượng các yếu tố địa chất hoặc thuộc tính đá chứa nhằm xác định cấu trúc hoặc môi trường lắng đọng trầm tích và nội suy các thuộc tính khác. Việc nghiên cứu đặc điểm môi trường lắng đọng trầm tích Miocen giữa trong khu vực nghiên cứu được nhóm tác giả thực hiện theo sơ đồ sau (Hình 5).

\section{Kết quả nghiên cứu}

\section{1. Đặc điểm thạch học trầm tích Miocen giữa}

Theo kết quả phân tích các mẫu lát mỏng thạch học cho thấy, trong phạm vi cấu tạo Thiên Ưng - Mãng Cầu tồn tại 2 nhóm đá trầm tích chính như sau: (1) nhóm đá trầm tích lục nguyên (hay nhóm đá vụn cơ học), (2) nhóm đá cacbonat.

Nhóm đá trầm tích lục nguyên gặp ở tất cả các giếng khoan và phân bố ở nhiều khoảng độ sâu khác nhau, phân lớp xen kẹp (Hình 6). Theo phân loại của Pettijohn, 1975 cát kết trong khu vực gồm các loại cát kết acko (Hình 7), cát kết acko - litic (Hình 8 ), cát kết grauvac (Hình 9) và cát kết grauvac - litic. Cát kết và bột kết ở đây đều có các

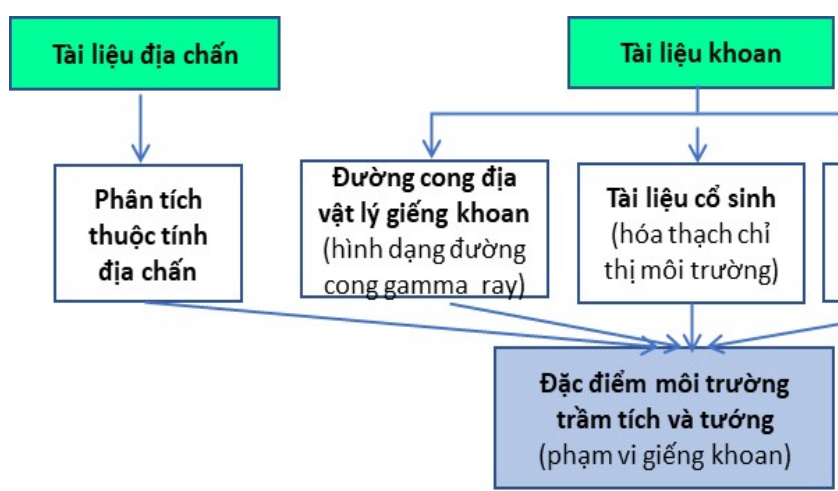

Hình 5: Workflow trong nghiên cứu đặc điểm môi trường trầm tích Miocen giữa, khu vực Thiên Ưng Mãng Cầu, lô 04 - 3.

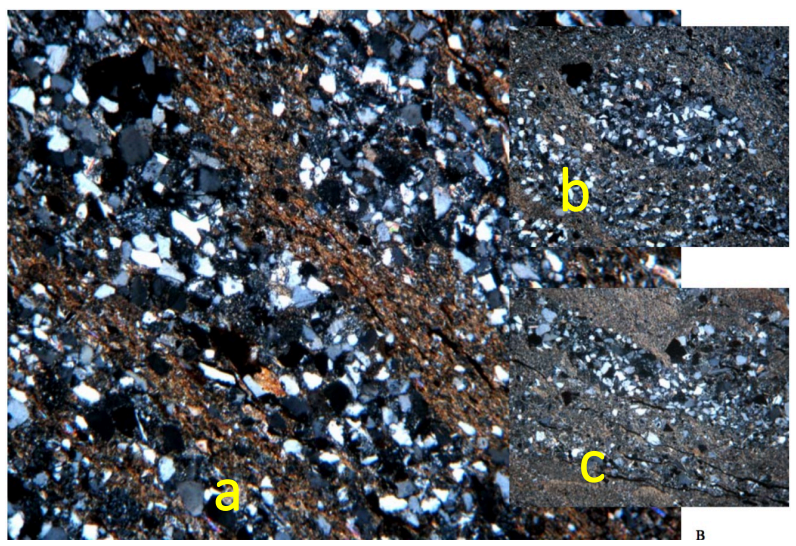

Hình 6. Các lớp cát kết, sét kết vôi xen kẹp độ sâu lần lươt a) 3150,65 m; b) 3151,4 m; c) 3152,9 m; GK C $3 X, N+$; tuổi N12, độ phóng đại a) 50 lần; b,c) 25 lần (NIPI, VSP).

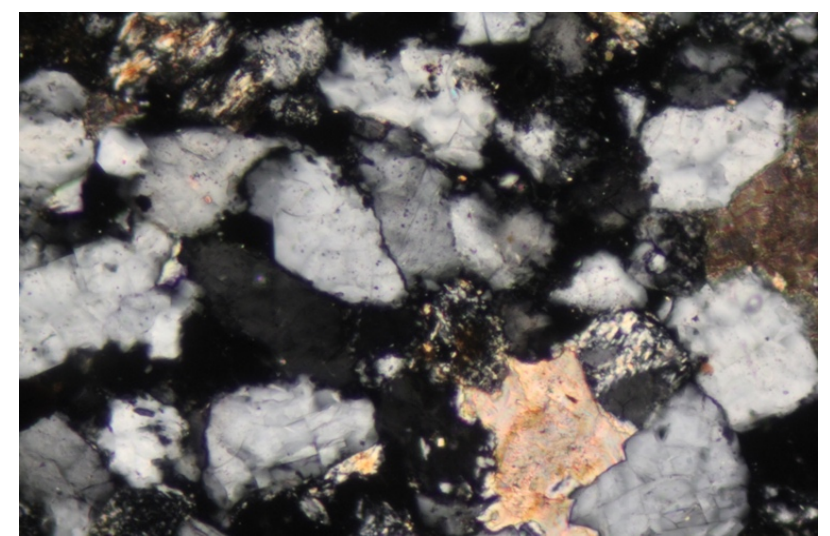

Hình 7. Cát kết acko hạt trung, độ chọn lọc và mài tròn trung bình $(S o=2,1, R o=0,5)$, xi măng silic lấp đầy, 3031,20 m; GKC - 2X, $N^{+}$, tuổi $N_{1}^{2} ; F O V=0,53$ $\mathrm{mm}$. 
kiến trúc hạt lớn, hạt trung và hạt nhỏ và nhiều kiểu cấu tạo khác nhau. Về thành phần khoáng vật, gồm có thạch anh, fenspat, mica và mảnh đá; xi măng thường có kiểu cơ sở - lấp đầy, thành phần xi măng gồm matrix, sét, vật chất hữu cơ, nhiều lát mỏng có xi măng cacbonat; khoáng vật phụ có pyrit. Đáng chú ý, trong các lớp bột kết có chứa các lớp rong tảo (Hình 10 ) và các dải vật chất hữu cơ, bitum. Đối với sét kết, quan sát được thành phần bitum phân bố thành dải, không đều (Hình 11).

Đặc biệt, trầm tích Miocen giữa trong khu vực nghiên cứu xuất hiện trầm tích cabonat phân bố ở tất cả 4 giếng khoan, gồm đá vôi, dolomit và dolomit vôi. Theo kết quả phân tích lát mỏng thạch học, kiến trúc đá trầm tích cacbonat ở đây khá đa dạng, gồm các tinh thể canxit dạng tấm và hạt lớn (Hình 12), có mẫu gồm các tinh thể dolomit hạt

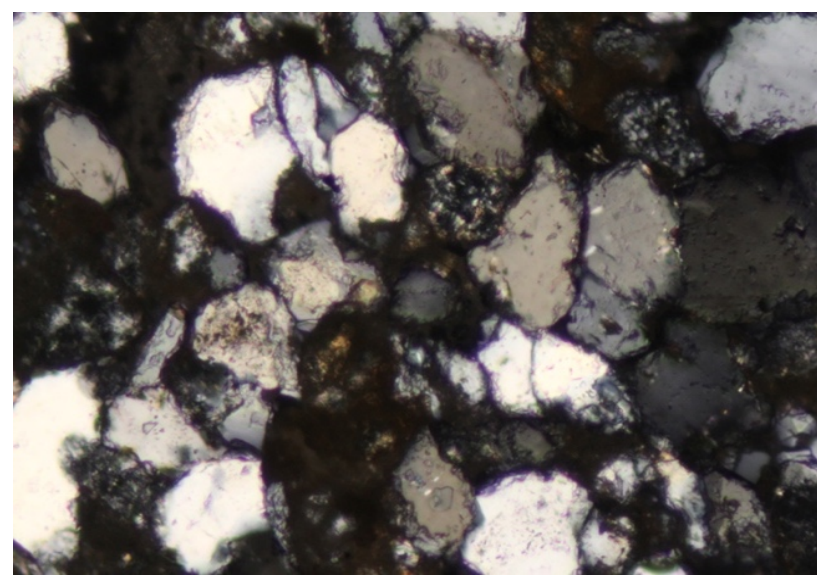

Hình 8. Cát kết acko - litic hạt nhỏ, xi măng silic, độ chọn lọc trung bình, độ mài tròn tốt; độ sâu 3031,80 m; GKC - 2X, $\mathrm{N}^{+}$, tuổi $\mathrm{N}_{1}^{2} ; \mathrm{FOV}=0,53 \mathrm{~mm}$.

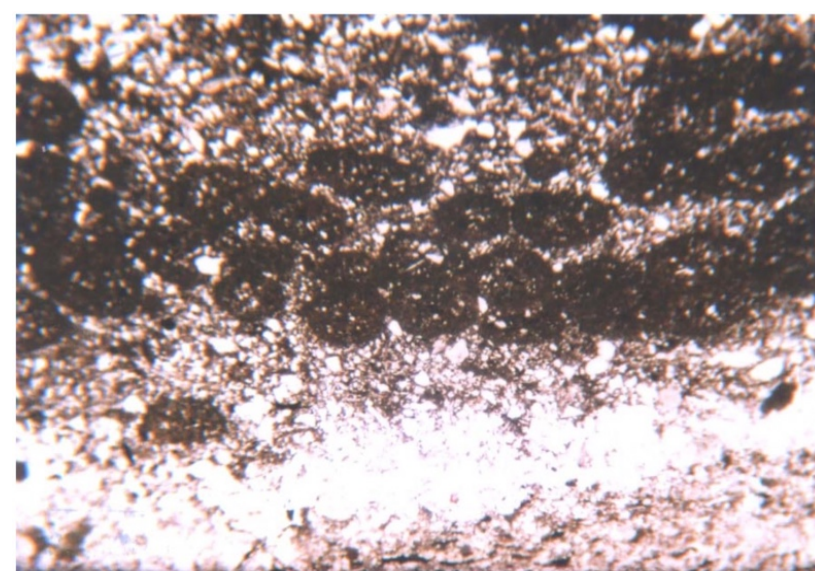

Hình 10. Bôt kết chứa nhiều lóp tảo, 3034,2 m, GKC - 2X, độ phóng đại 40 lần, $N^{+}$, tuổi $N_{1}^{2}$. nhỏ và vi hạt (Hình 13), có chứa mảnh vụn vỏ sinh vật hoặc Foraminifera bám đáy (Hình 14).

\section{2. Đặc điểm môi trường trầm tích Miocen giữa}

Áp dụng phương pháp minh giải môi trường lắng đọng trầm tích trên cơ sở hình dạng đường cong gamma ray như đã đề cập ở phần phương pháp nghiên cứu, kết hợp với các kết quả phân tích đặc điểm thạch học nói trên và tham khảo kết quả nghiên cứu cổ sinh địa tầng của VPI - Labs (Viện Dầu khí Việt Nam, 2005, 2006), bài báo đã tiến hành xác định môi trường lắng đọng chi tiết cho từng khoảng trầm tích Miocen giữa của các giếng khoan $\mathrm{C}-1 \mathrm{X}, \mathrm{C}-2 \mathrm{X}, \mathrm{C}-3 \mathrm{X}$ và $\mathrm{C}-4 \mathrm{X}$.

Ví dụ đối với giếng khoan $\mathrm{C}-1 \mathrm{X}$, trong khoảng độ sâu $2.700 \div 2.720$ mm (Hình 17), đường cong

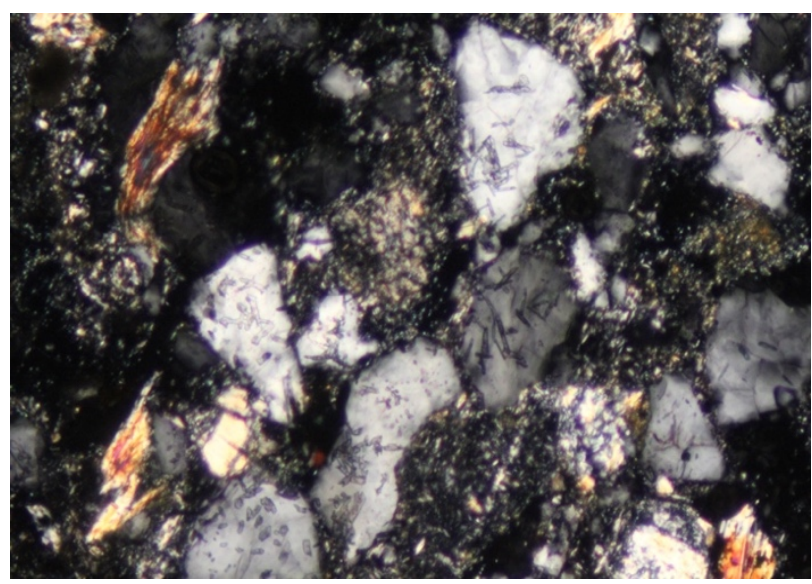

Hình 9. Cát kết grauvac hạt trung, độ chọn lọc trung bình $(S o=2,0)$, mài tròn tốt $(R o=0,6)$, xi măng co sơ - lấp đầy; độ sâu 2651,50 m, GKC - 1X, $N^{+}$, tuổi $N_{1}^{2}$ $F O V=0,53 \mathrm{~mm}$.

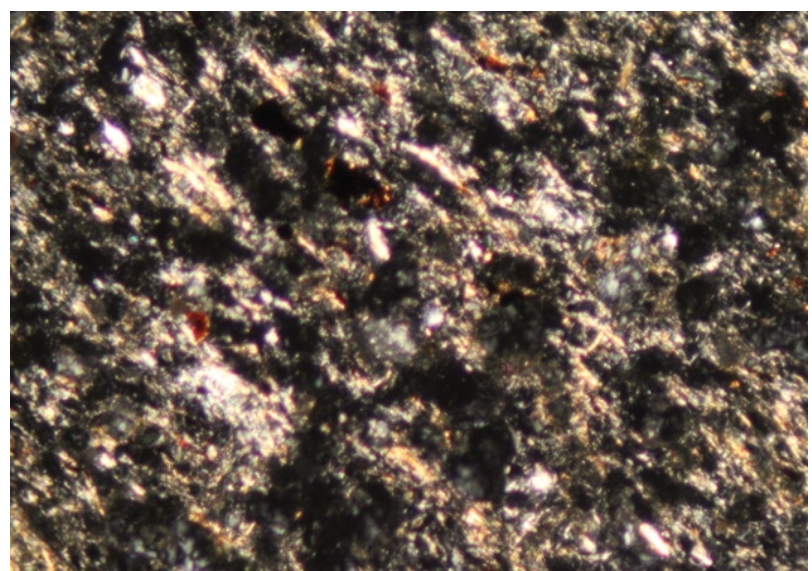

Hình 11. Sét kết có dấu hiệu bị sericit hóa, 3033,8 m, GKC $-2 X, N^{+}, F O V=0,53 \mathrm{~mm}$, tuổi $\mathrm{N}_{1}^{2}$. 


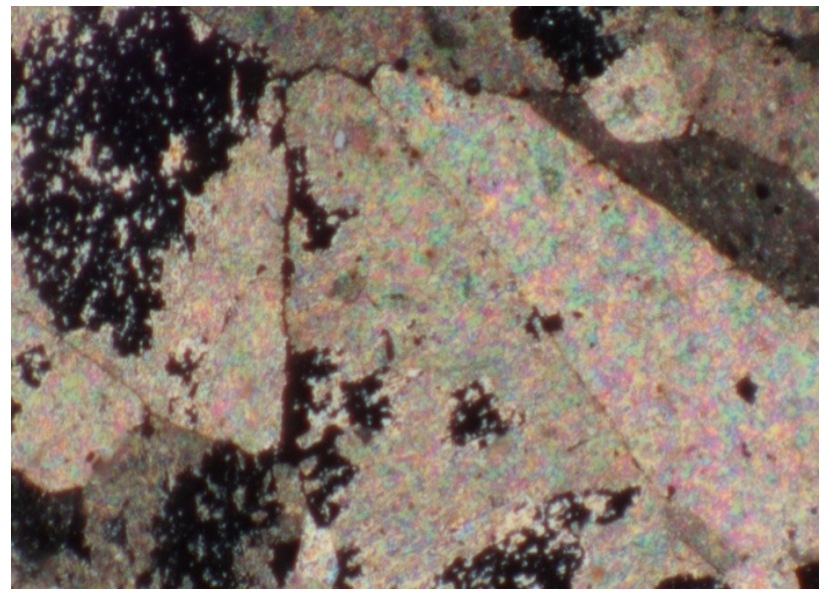

Hình 12. Đá vôi vi hạt ở độ sâu 2644,2 m, GKC - 1X, $N^{+}, F O V=1,4 \mathrm{~mm}$, tuổi $N_{1}^{2}$.

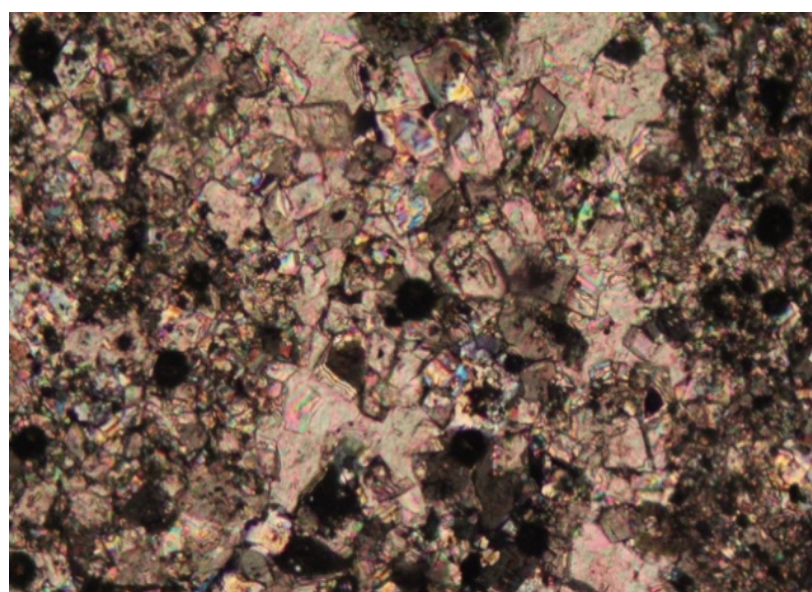

Hình 13. Đá vôi dolomit nguyên sinh; dolomit tinh thế hình thoi tự hình, canxit dạng tấm, bitum màu đen xâm tán đều, độ sâu 2650,1 m; GKC - 1X, N+, FOV = $1,4 \mathrm{~mm}$, tuổi $\mathrm{N}_{1}^{2}$.

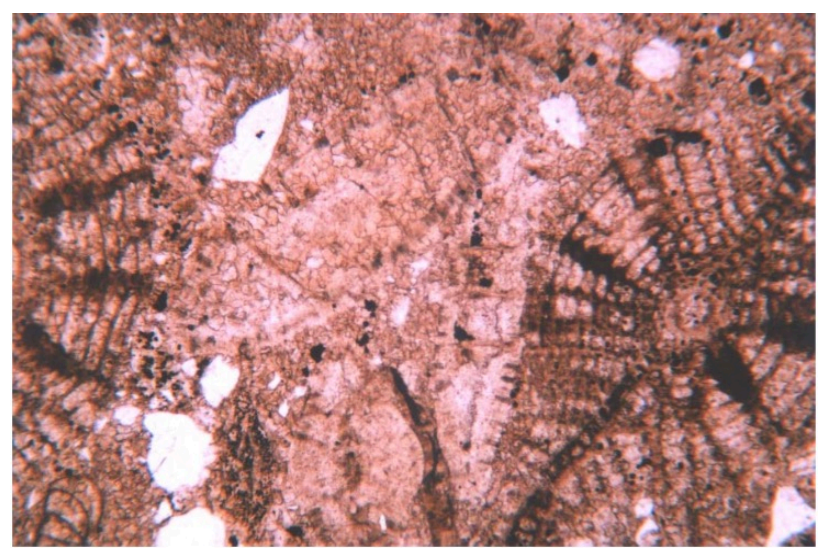

Hình 14. Đá vôi dolomit có chứa Foraminifera bám đáy, ở giếng khoan C - 1X; độ sâu 2703,6 m, độ phóng đại 40 lần (NIPI, VSP). gamma ray có hình dạng răng cưa nên có thể chúng được hình thành trong môi trường đồng bằng ngập lũ (fluvial flood plain) hoặc ở khu vực biển nông, xa bờ (distal shelf) hoặc ở sườn lục địa (deep - marine slope). Kết hợp với tài liệu minh giải thạch học có sự thay đổi về thành phần thạch học: từ cát, bột, sét sang cacbonat; kết hợp phân tích cấu tạo từ mẫu lõi cho thấy đá trầm tích có cấu tạo "giả turbidite" (Hình 15) (Phạm Bảo Ngọc, 2019). Đây là kiểu cấu tạo đặc trưng cho môi trường biển nông có dòng chảy đáy hoạt động tương đối mạnh làm xáo trộn các lớp trầm tích lắng đọng trước đó. Ngoài ra, trên lát mỏng thạch học đá vôi chứa cát ở độ sâu 2.703,6 m có chứa hoá thạch foram, hoá thạch này chỉ thị cho môi trường biển nông (Hình 16).
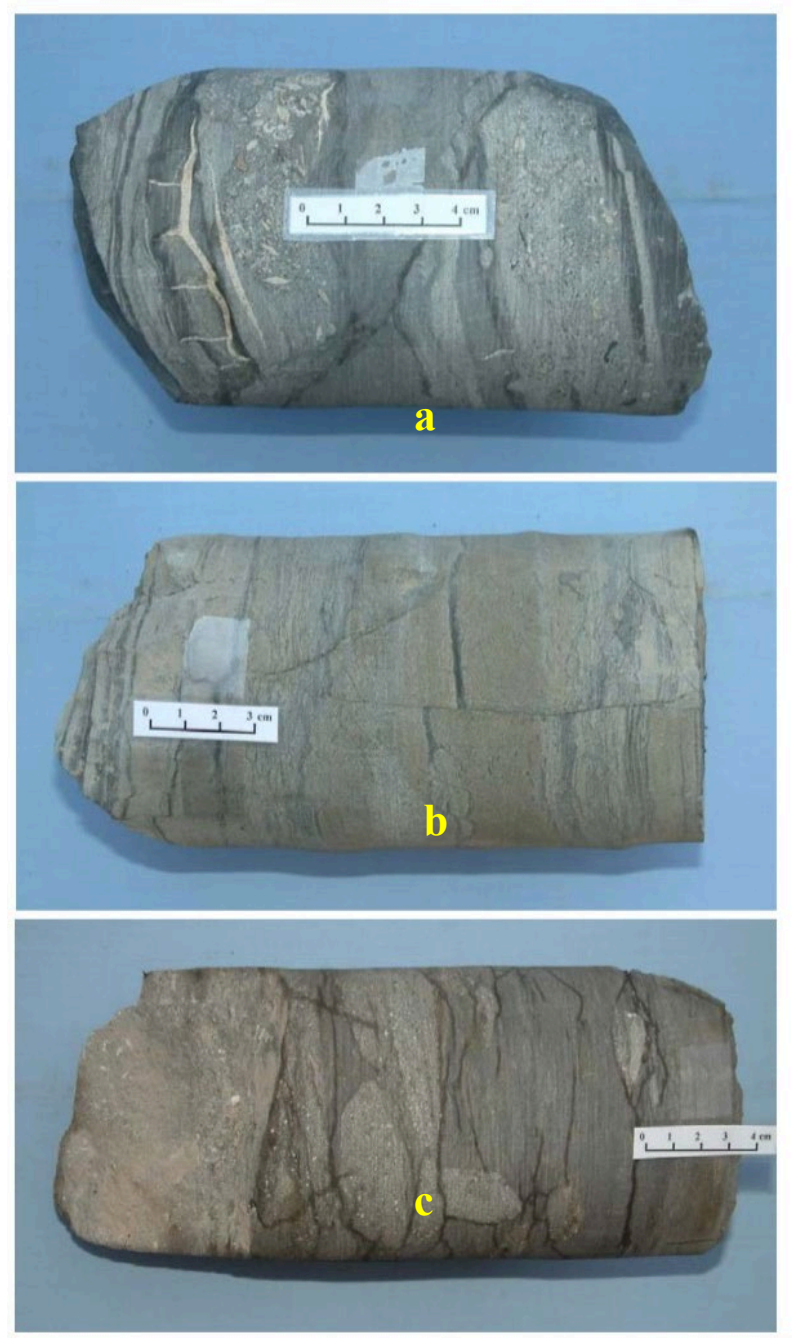

Hình 15. Cấu tạo "giả turbidite" được thành tạo trong môi trường biển nông, vũng vịnh $C-1 X$ (a: $2704,3 \div 2704,45 \mathrm{~m} ; b: 2706,5 \div 2706,7 \mathrm{~m}$; : 2708,15 $\div 2708,35 \mathrm{~m})($ Pham, 2019). 
Phần đường cong gamma ray thể hiện trầm tích cacbonat có dạng hình trụ đặc trưng cho kiểu cacbonat keep - up được hình thành trong môi trường biển nông, vũng vịnh với bối cảnh tốc độ hình thành trầm tích cacbonat bắt kịp với tốc độ nước biển tăng cao. Như vậy có thể kết luận môi trường trầm tích trong khoảng độ sâu $2.700 \div 2.720 \mathrm{~m}$ là môi trường biển nông với giai đoạn đầu chịu ảnh hưởng của dòng chảy đáy

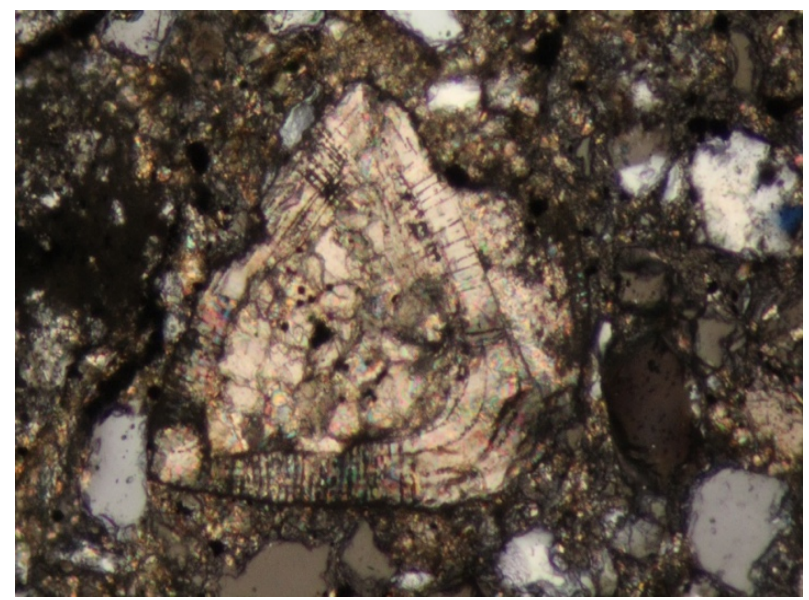

Hình 16. Đá vôi chứa cát, chứa foram, chỉ thị cho môi trường biển nông, độ sâu 2703,6 m, GKC - 1X, $N^{+}, F O V=1,4$ mm, tuổi $N_{1}^{2}$ (Phạm, 2019).

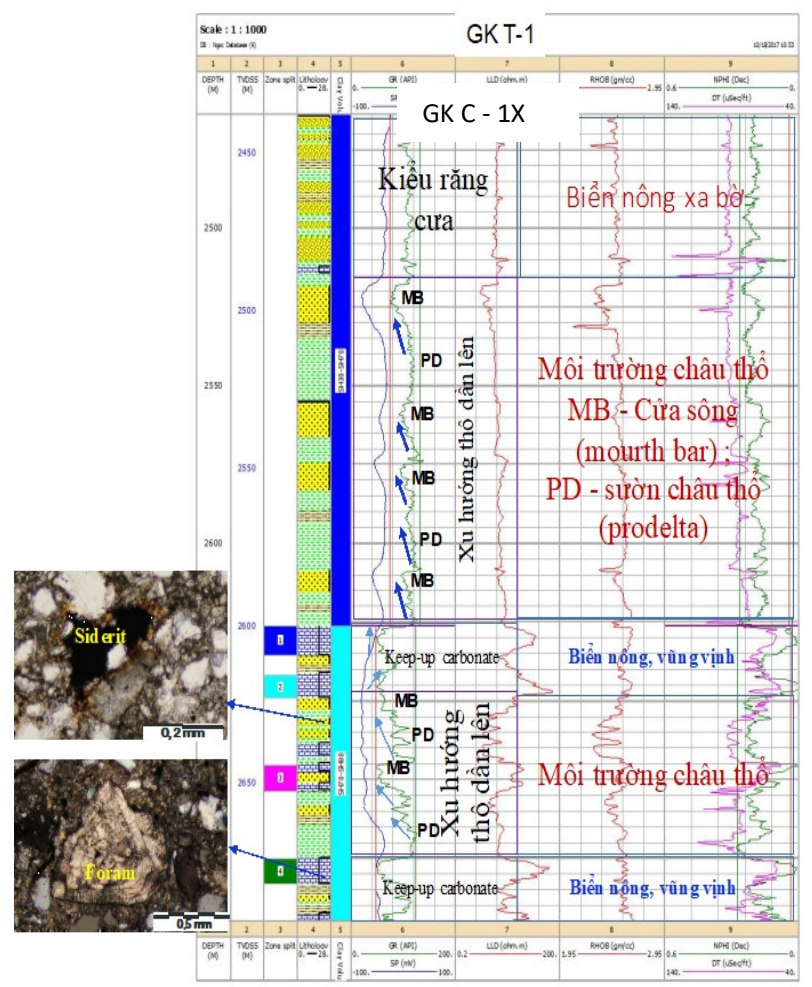

Hình 17. Kết quả minh giải môi trường lắng đọng trầm tích theo độ sâu, giếng khoan $C$ - $1 X$. manh hơn, nên trầm tích bi xáo trộn, tạo ra kiểu trầm tích hỗn hợp với cấu tạo "giả turbidite" nói trên; và giai đoạn sau tương đối yên tĩnh để hình thành tập cacbonat.

Đối chiếu với kết quả phân tích cổ sinh của Trung tâm phân tích, Viện Dầu khí Việt Nam cũng quan sát được các hoá thạch đặc trưng cho môi trường biển nông (Viện Dầu khí Việt Nam, 2005). Cụ thể, trong khoảng độ sâu từ 2.703,0 $\div 2.703,7$ m, trong thành phần tàn dư sinh vật có xuất hiện các loại Foraminifera xanh đáy và và trôi nổi (Xinofei bám) và Tảo đỏ, các mảnh vỏ sinh vật lớn, tái kết tinh không rõ ràng (Pelecypoda). Có nơi quan sát thấy vỏ rỗng hình cầu, một buồng, được cho là Foraminifera và được lấp đầy bởi xi măng. Tiếp đến khoảng độ sâu $2.906,8 \div 2.708,13$ m, trong tập bột kết quan sát thấy khá nhiều mảnh sinh vật có độ bảo tồn kém (chiếm khoảng từ $5 \div 25 \%$ ), gồm các dạng Forraminifera bám đáy, Da Gai và Ốc gai.

Tương tự như vậy, tập thể tác giả phân tích, minh giải môi trường lắng đọng trầm tích cho các khoảng độ sâu khác của giếng $C$ - $1 X$ cũng như 3 giếng khoan còn lại, gồm $\mathrm{C}-2 \mathrm{X}, \mathrm{C}-3 \mathrm{X}$ và $\mathrm{C}-4 \mathrm{X}$. Kết quả cho thấy trong phạm vi nghiên cứu, trầm tích Miocen giữa được lắng đọng ở các kiểu môi trường sau: môi trường biển nông (gồm biển nông thuận lợi cho thành tạo các ám tiêu san hô shallow marine; biển nông ven bờ - shoreline; và biển nông xa bờ, có dòng chảy đáy hoạt động distal shelf) và môi trường châu thổ (cửa sông mouth bar; tiền châu thổ - delta front; sườn châu thổ - prodelta; và đồng bằng châu thổ, phần thấp lower deltaic plain).

Qua tài liệu địa vật lý giếng khoan cho thấy, quy luận phân bố môi trường trầm tích theo thời gian thay đổi có tính chu kì, luân phiên giữa 2 nhóm chính là môi trường biển nông và môi trường châu thổ (Hình 17). Sự thay đổi này bị chi phối trực tiếp bởi sự thay đổi mực nước biển trong khu vực.

\subsection{Mô hình phân bố trầm tích cacbonat Miocen giữa trên co' sở phân tích thuộc tính địa chấn}

Theo kết quả minh giải thạch học, cacbonat là một trong những đối tượng phân bố tương đối dày ở hai mặt phản xạ nội tầng là $\mathrm{P} 1$ và $\mathrm{P} 2$. Do đó, tập thể tác giả tiến hành phân tích kĩ sự phân bố trầm tích này nhằm đưa ra những đánh giá về mô hình lắng đọng trầm tích Miocen giữa của khu vực nghiên cứu. 
Trong quá trình chạy các thuộc tính địa chấn cho đối tượng cacbonat, nhóm tác giả đã chạy lần lượt các thuộc tính địa chấn theo hai nhóm gồm nhóm thuộc tính địa chấn theo bề mặt (surface seismic attributes) và nhóm thuộc tính địa chấn theo khối (volume seismic attributes). Trên cơ sở kết quả thu được, nhóm tác giả lựa chọn các thuộc tính cho kết quả thể hiện rõ sự phân bố của đá cacbonat.

Phân tích các kết quả chạy các thuộc tính địa chấn bề mặt cho thấy, thuộc tính RMS, Maximum Amplitude và Sum of Positive Amplitude thể hiện sự phân bố trầm tích cacbonat rõ nhất cho cả 2 mặt phản xạ chính P1 và P2 (Hình 18, 19, 20). Diện phân bố trầm tích này trên các bản đồ chính là các khu vực có màu vàng, xanh lá và xanh ngọc. Kết quả phân tích bằng thuộc tính RMS và Maximum Amplitude phản ánh khá rõ tầng cacbonat ở mặt phản xạ P1, trong khi mặt phản xạ P2 thể hiện trầm tích cacbonat ám tiêu tập trung tại khối nâng Trung tâm và phía Đông, giảm dần ở khu vực phía Tây. Quy luật phân bố này thể hiện rõ trên mặt cắt thuộc tính tương ứng

Các sơ đồ dự báo sự phân bố của tập đá vôi P1 theo tài liệu thuộc tính địa chấn tổng biên độ dương (Hình 20) cho kết quả phù hợp với kết quả
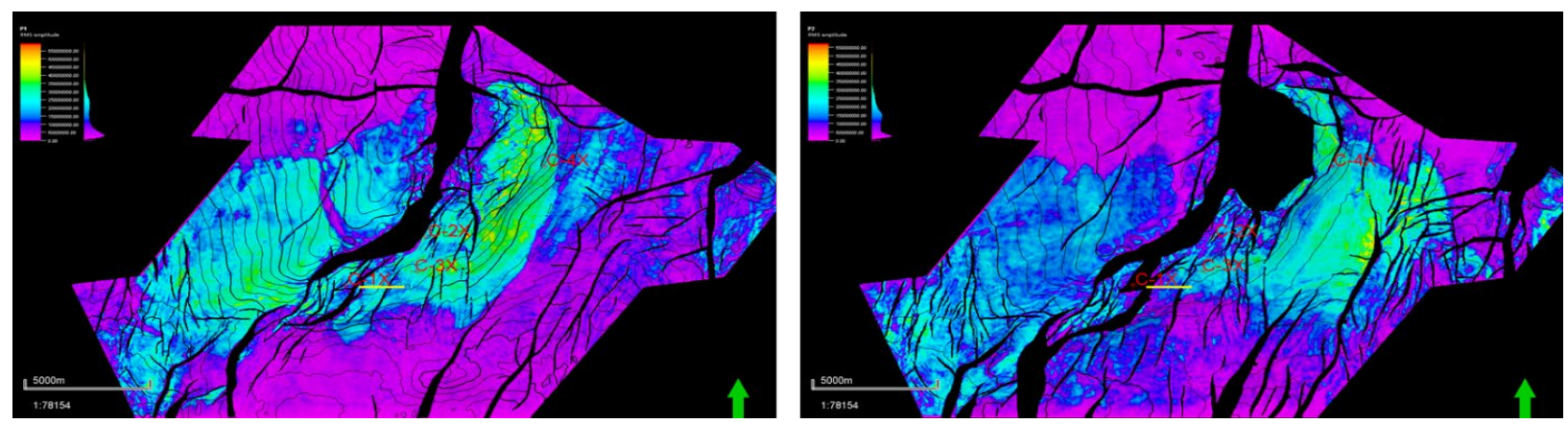

Hình 18. Sự phân bố trầm tích cacbonat ám tiêu trên các mặt phản xạ P1 (trái) và P2 (phải) trên cơ sở phân tích thuộc tính RMS.
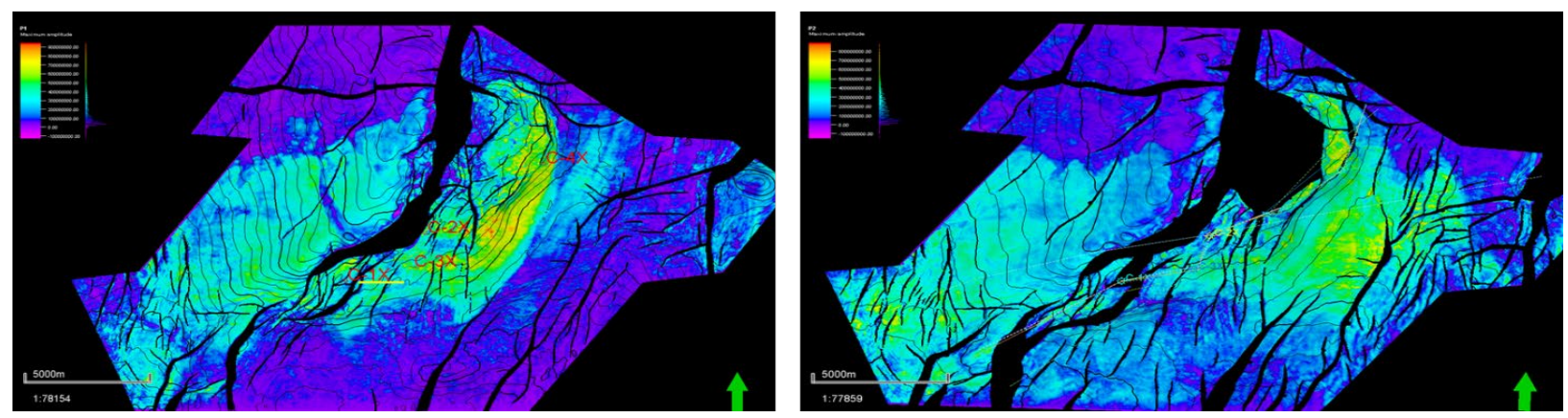

Hình 19. Sự phân bố trầm tích cacbonat ám tiêu trên các mặt phản xạ P1 (trái) và P2 (phải) trên cơ sở phân tích thuộc tính Maximum Amplitude.
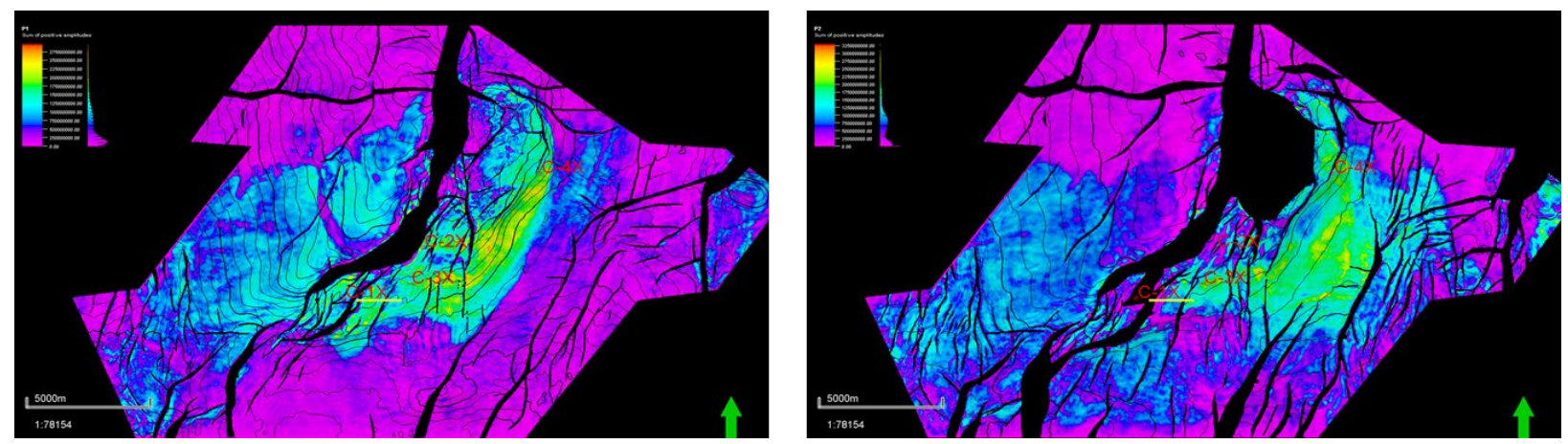

Hình 20. Sự phân bố trầm tích cacbonat ám tiêu trên các mặt phản xạ P1 (trái) và P2 (phải) trên cơ sở phân tích thuộc tính địa chấn tổng biên độ dưong (Sum of Positive Amplitude). 
minh giải tài liệu địa vật lý giếng khoan (Hình 21). Cụ thể đặc điểm phân bố như sau: trầm tích cacbonat ám tiêu chủ yếu phân bố ở nóc tập tầng P1, phân bố xung quanh đới nâng trung tâm, và càng ra xa đới nâng thì diện phân bố giảm dần. Theo mặt cắt từ giếng khoan $\mathrm{C}-1 \mathrm{X}, \mathrm{C}-2 \mathrm{X}, \mathrm{C}-3 \mathrm{X}$ đến $\mathrm{C}-4 \mathrm{X}$ cho thấy rằng tập cacbonat có xu hướng dày lên đáng kể, từ $52 \mathrm{~m}$ tại giếng khoan $\mathrm{C}$ - $1 \mathrm{X}$ đến $148 m$ tại giếng khoan $\mathrm{C}-4 \mathrm{X}$. Điều này cũng phản ánh trên các mặt cắt thuộc tính địa chấn, khu vực có dị thường biên độ lớn chủ yếu tập trung tại khu vực giếng khoan $\mathrm{C}-2 \mathrm{X}$ và $\mathrm{C}-4 \mathrm{X}$.

Dựa trên kết quả phân tích tài liệu thuộc tính địa chấn cho thấy quy luật tương tự với đối tượng P2. Thuộc tính biên độ đa phần tập trung tại nóc vỉa và khu vực đới nâng trung tâm.

Mặt cắt liên kết giếng khoan cho thấy cacbonat ám tiêu chủ yếu phân bố ở nóc tầng P1, mỏng nhất ở giếng khoan $\mathrm{C}-1 \mathrm{X}$ và dày dần từ giếng khoan $\mathrm{C}-2 \mathrm{X}$ đến $\mathrm{C}-4 \mathrm{X}$ (tại giếng khoan $\mathrm{C}$ $1 X$ là $52 \mathrm{~m}, \mathrm{C}-2 \mathrm{X}$ là $112 \mathrm{~m}$ và $\mathrm{C}-4 \mathrm{X}$ là $148 \mathrm{~m}$ ). Điều này khá phù hợp với xu hướng thay đổi của biên độ RMS cũng như tổng biên độ dương Sum of Positive Amplitudes (màu xanh ngọc từ giếng khoan $\mathrm{C}$ - $1 \mathrm{X}$ đến màu xanh lá và vàng về phía $\mathrm{C}$ $4 \mathrm{X})$.
Tiếp theo, nhóm tác giả tiến hành phân tích thuộc tính khối, lựa chọn Time slice khác nhau (Hình 22) trên tài liệu nhằm làm sáng tỏ sự phân bố và bề dày của trầm tích cacbonat ám tiêu (Hình 23). Đối với thuộc tính địa chấn khối, bài báo cũng phân tích trên cơ sở các thuộc tính RMS, Maximum Amplitude và Sum of Positive Amplitude thì chỉ có thuộc tính RMS làm nổi bật đối tượng cacbonat nhất. Quan sát sơ đồ phân bố cacbonat cho tập P1 - P2 theo thuộc tính RMS cho thấy khu vực khối nâng Trung Tâm cũng như cánh phía Tây của khối nâng Trung Tâm có biên độ RMS khá cao thể hiện bằng màu vàng trên bản đồ phân bố.

Ngoài ra, theo kết quả phân tích địa tầng phân tập (Phạm, 2019), trước đó, bề mặt phản xạ P1 tương ứng với giai đoạn miền hệ thống trầm tích biển thoái (Lowstand Systems Tract - LST), tại thời điểm này mực nước biển hạ thấp, làm tiền đề cho sự tồn tại phổ biến môi trường biển nông và tạo điều kiện cho các ám tiêu san hô phát triển. Chính vì vậy, quan sát trên sơ đồ phân bố cacbonat cho mặt P1 dựa theo thuộc tính địa chấn (Hình 18, 19, 20 trái) cho thấy diện phân bố tương đối rộng. Trong khi đó, mặt phản xạ P2 tương ứng với thời kì biển tiến (Transgressive Systems Tract - TST), các tập cacbonat hình thành với tốc độ bắt kịp

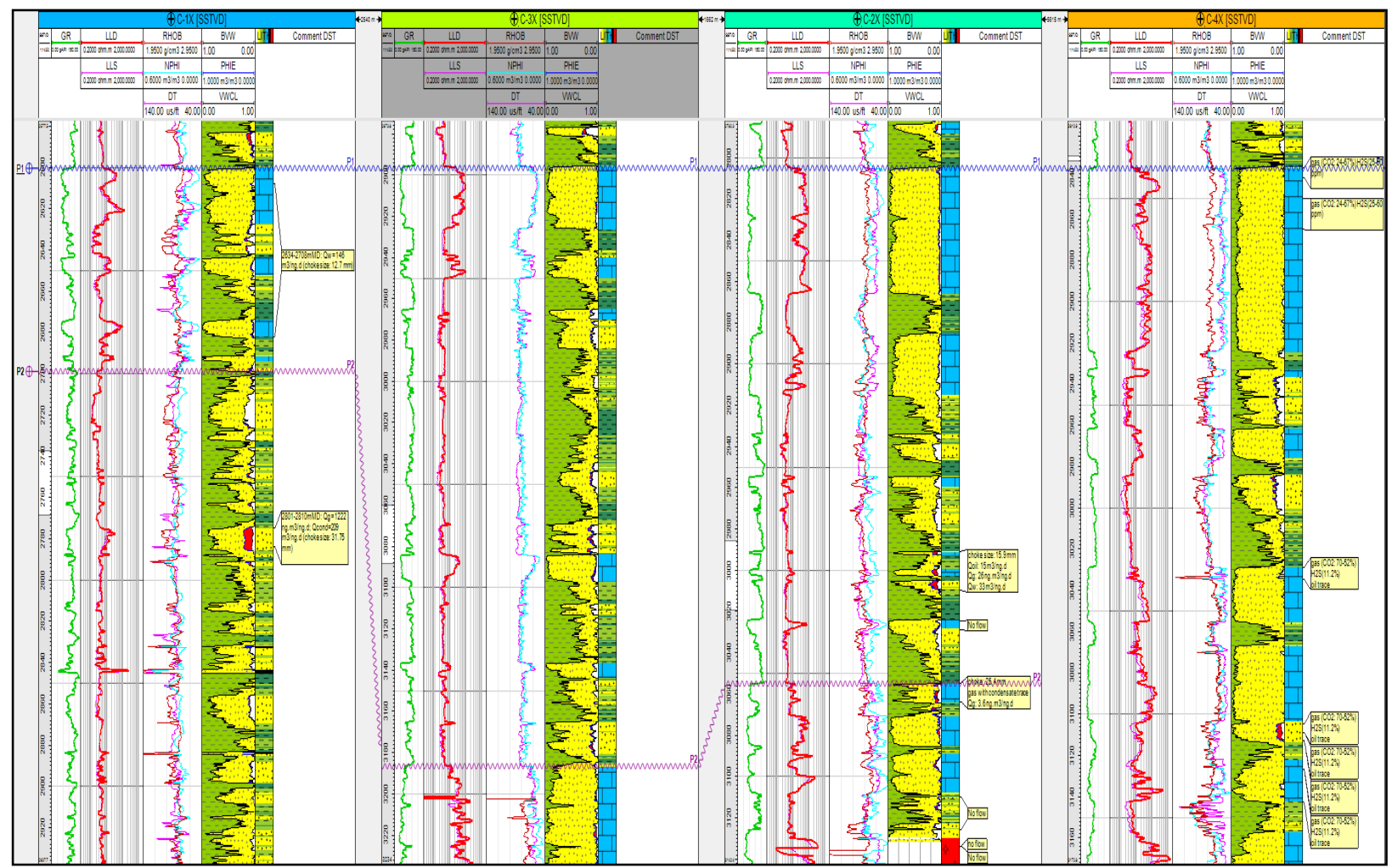

Hình 21. Mặt cắt liên kết giếng khoan $C-1 X, C-2 X, C-3 X$ và $C-4 X$. 

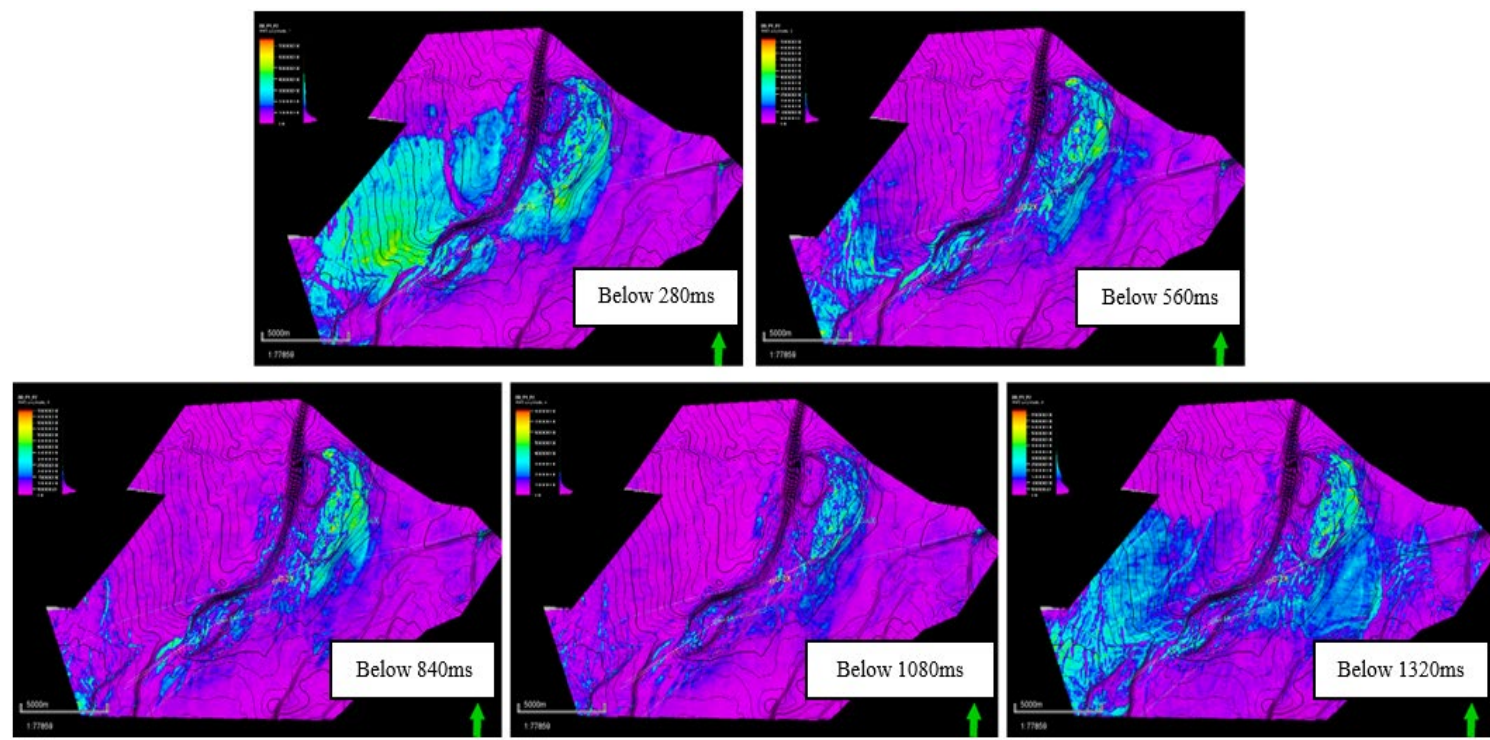

Hình 22. Sự phân bố trầm tích cacbonat ám tiêu theo time slice.

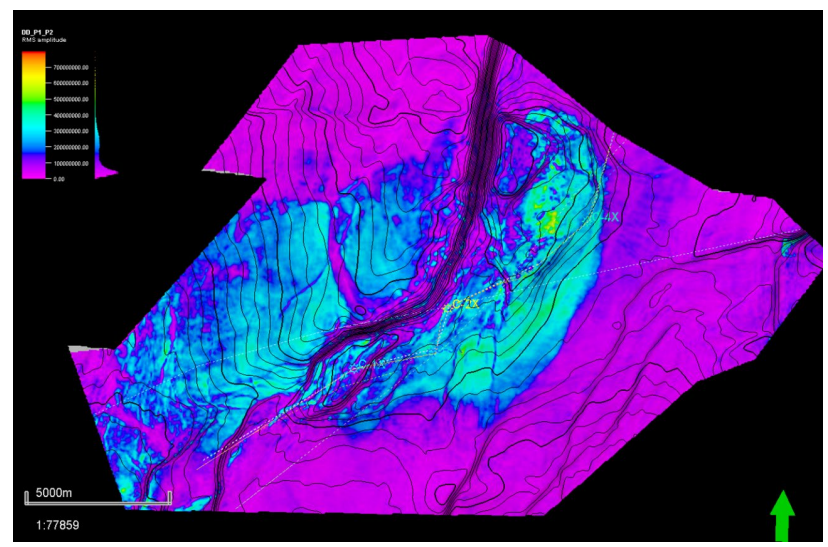

Hình 23. Sơ đồ phân bố cacbonat ám tiêu cho tập P1 - P2 theo thuộc tính RMS.

tương đối tốc độ dâng cao mực nước biển (cacbonat kiểu keep - up) (Hình 17). Điều này cũng phù hợp với xu thế trên sơ đồ phân bố cacbonat trên cơ sở phân tích thuộc tính địa chấn (Hình 18, 19, 20 phải): diện phân bố trên mặt phản xạ P2 nhỏ hơn P1, cacbonat tập trung chủ yếu ở cánh nâng của đứt gãy chính trong khu vực.

\section{Kết luận}

Theo kết quả minh giải môi trường lắng đọng từ tài liệu địa vật lý giếng khoan cho thấy trầm tích Miocen giữa của khu vực được thành tạo trong các bối cảnh sau: môi trường biển nông (gồm biển nông thuận lợi cho thành tạo các ám tiêu san hô; biển nông ven bờ; và biển nông xa bờ, có dòng chảy đáy hoạt động) và môi trường châu thổ (cửa sông; tiền châu thổ; sườn châu thổ; và đồng bằng châu thổ, phần thấp). Kết hợp với các phân tích về thạch học và cổ sinh từ các khoảng địa tầng có mẫu lõi cho thấy trong thành phần cát/bột kết cũng như đá cacbonat xuất hiện khá phổ biến các thành phần vật chất hữu cơ như rong tảo, bitum; đặc biệt là các hoá thạch Foraminifera xanh đáy và trôi nổi (Xinofei bám), các tàn dư của mảnh sinh vật bảo tồn kém của $D a$ Gai và Ốc Gai. Một số mẫu còn phát hiện sét glauconit. Những đặc điểm này chỉ thị cho môi trường lắng đọng trầm tích biển nông. Ngoài ra, khi phân tích đặc điểm thạch học còn phát hiện trong trầm tích bột, sét có chứa các kết hạch cacbonat và quặng siderit - điều này chứng tỏ trầm tích này được thành tạo trong môi trường sườn châu thổ. Các khoảng độ sâu được kết luận về môi trường lắng đọng từ các mẫu thạch học này hoàn toàn tương ứng với các khoảng trong tài liệu 
địa vật lý giếng khoan.

Đá trầm tích cacbonat Miocen giữa trong khu vực là đối tượng đáng chú ý do đặc điểm phân bố khá tập trung, cụ thể là phân bố rộng khắp ở các bề mặt phản xạ P1 và $\mathrm{P} 2$. Theo kết quả minh giải môi trường của các tập cacbonat này là môi trường biển nông. Quan sát kết quả phân bố trầm tích cacbonat trên cơ sở phân tích thuộc tính cho thấy, trầm tích này phân bố chủ yếu ở mặt phản xa $P 1$ và $P 2$, xung quanh hai khối nâng Thiên Ưng và Mãng Cầu. Điều này hoàn toàn phù hợp với các quy luật và nguyên lý về lắng đọng trầm tích: môi trường biển nông chính là khu vực bao quanh khối nâng là điều kiện thuận lợi cho sự phát triển của các ám tiêu san hô.

\section{Lò̀i cảm ơn}

Nhóm tác giả xin chân thành cảm ơn Trường Đại học Dầu khí Việt Nam đã tài trợ trong khuôn khổ đề tài mã số GV1904. Đồng thời, cũng gửi lời cảm ơn đến Viện Nghiên cứu Khoa học và Thiết kế Dầu khí biển và Viện Dầu khí Việt Nam đã tạo điều kiện tham khảo tài liệu quý báu trong quá trình thực hiện bài báo.

\section{Đóng góp của các tác giả}

Phạm Bảo Ngọc - phân tích thạch học, minh giải tài liệu địa vật lý giếng khoan, viết nội dung bài báo; Trần Trung Đồng - phân tích thuộc tính địa chấn; Trần Thị Oanh - minh giải tài liệu địa vật lý giếng khoan; Trần Nghi - cố vấn và rà soát toàn bộ nội dung của bài báo.

\section{Tài liệu tham khảo}

Radwan, A. E. (2021). Modeling the depositional environment of the sandstone reservoir in the Middle Miocene Sidri Member, Badri Field, Gulf of Suez Basin, Egypt: Integration of gamma-ray log patterns and petrographic characteristics of lithology. Natural Resources Research, 30(1), 431-449.
Cant, D. (1992). Subsurface Facies Analysis. In R. G. Walker (Ed), Facies models. response to sea level changes. St. John's: Geological Association of Canada, 27-45.

Chow, J. J., Ming-Chung, L., \& Fuh, S. C. (2005). Geophysical well log study on the paleoenvironment of the hydrocarbon producing zones in the Erchungchi Formation, Hsinyin, SW Taiwan. TAO: Terrestrial, Atmospheric and Oceanic Sciences, 16(3), 531.

Mai, T. T. (2011). Thăm dò địa chấn, Nhà xuất bản Giao thông vận tải, Hà Nội.

Nguyễn, H. (2005). Địa chất và Tài nguyên Dầu khí Việt Nam. Chương 10 - Bể trầm tích Nam Côn Sơn và tiềm năng dầu khí, NXB Khoa học và Kỹ thuật, Hà Nội.

Serra, O. (eds.). (1989). Sedimentary Environments from wireline logs. Schlumberger Educational Services.

Phạm, B. N. (2019). Nghiên cứu tiến hoá môi trường trầm tích và ý nghĩa dầu khí trầm tích Miocen giữa, khu vực trung tâm bể Nam Côn Sơn. Luận án Kỹ thuật Dầu khí. Viện Dầu khí Việt Nam.

Selley, R. C. (1978). Concepts and methods of subsurface facies analysis. American Associatetion of Petroleum Geologists Contin Educ Course Notes Ser. 9, 82.

Viện Dầu khí Việt Nam. (2005). Sinh địa tầng giếng khoan 04.3 - TU - 1X, bể Nam Côn Sơn, thềm lục địa Việt Nam.

Viện Dầu khí Việt Nam. (2006). Sinh địa tầng giếng khoan 04.3 - TU - 2X, bể Nam Côn Sơn, thềm lục địa Việt Nam.

Vietsovpetro. (2011). Tính trũ lượng dầu và khí mỏ Thiên Ưng - Mãng Cầu tính đến thời điểm 01.05.2009. Liên doanh Việt - Nga. 